\title{
Indoor and Outdoor Particulate Matter Exposure of Rural Interior Alaska Residents
}

\author{
Stanley G. Edwinn ${ }^{1,2}$, Nicole Mölders ${ }^{2,3^{*}}$ \\ ${ }^{1}$ Council of Athabascan Tribal Governments, Fort Yukon, USA \\ ${ }^{2}$ University of Alaska Fairbanks, College of Natural Science and Mathematics, Fairbanks, USA \\ ${ }^{3}$ University of Alaska Fairbanks, Geophysical Institute, Fairbanks, USA \\ Email: sedwin@alaska.edu, Stanley.edwin@catg.org, *cmoelders@alaska.edu
}

How to cite this paper: Edwin, S.G. and Mölders, N. (2020) Indoor and Outdoor Particulate Matter Exposure of Rural Interior Alaska Residents. Open Journal of Air Pollution, 9, 37-60.

https://doi.org/10.4236/ojap.2020.93004

Received: July 9, 2020

Accepted: September 21, 2020

Published: September 24, 2020

Copyright $\odot 2020$ by author(s) and Scientific Research Publishing Inc. This work is licensed under the Creative Commons Attribution International License (CC BY 4.0). http://creativecommons.org/licenses/by/4.0/

\section{Open Access}

\begin{abstract}
To assess the exposure of residents in rural communities in the Yukon Flats to particulate matter of $2.5 \mu \mathrm{m}$ or less in diameter $\left(\mathrm{PM}_{2.5}\right)$, both indoor and outdoor concentration observations were carried out from March to September 2019 in Ft. Yukon, Alaska. Indoor concentrations were measured at 0.61 $\mathrm{m}$ (breathing level during sleeping) in homes and at $1.52 \mathrm{~m}$ heights (breathing level of standing adult) in homes and office/commercial buildings. Air quality was better at both heights in cabins than frame homes both during times with and without surface-based inversions. In frame houses, concentrations were higher at $0.61 \mathrm{~m}$ than $1.52 \mathrm{~m}$, while the opposite is true typically for cabins. Differences between shoulder season and summer indoor concentrations in residences were related to changes in heating, subsistence lifestyle and mosquito repellents. In summer, office and commercial buildings, air quality decreased due to increased indoor emissions related to increased use of equipment and mosquito pics as well as more merchandise. During summer indoor concentrations reached unhealthy for sensitive groups to hazardous conditions for extended times that even exceeded the high outdoor concentrations. Due to nearby wildfires, July mean outdoor concentrations were $55.3 \mu \mathrm{g} \cdot \mathrm{m}^{-3}$ which exceeds the 24 -h US National Ambient Air Quality Standard of $35 \mu \mathrm{g} \cdot \mathrm{m}^{-3}$. Indoor and outdoor concentrations correlated the strongest with each other for office/commercial buildings, followed by frame houses and cabins. Office/commercial buildings with temperature monitors had one to two orders of magnitude lower concentrations than those without.
\end{abstract}

\section{Keywords}

Indoor Air Quality, Yukon Flats Alaska, Fine Particulate Matter, $\mathrm{PM}_{2.5}$ Exposure in Rural Alaska, Tribal Air Quality Study 


\section{Introduction}

During the harsh winter conditions of the Yukon Flats as well as during smoke episodes of the fire season in summer, residents of the villages of Eastern Interior of Alaska's Yukon Flats valley spend the majority of their time indoors. Exposure to fine particulate matter of $2.5 \mu \mathrm{m}$ or less in diameter $\left(\mathrm{PM}_{2.5}\right)$ is well known as health-adverse and can occur indoors as well as outdoors [1]. Poor indoor air quality was linked to respiratory problems especially in children, cancer, sick-building syndrome, fatigue, headache and about $6 \%$ - $9 \%$ reduced performance of office work, among others [2] [3].

Indoor emissions of $\mathrm{PM}_{2.5}$ stem from cooking, wood stoves, candles, household and office appliances, smoking, incense, insect repellent coils, cleaning, animals and heating [1]. Fine particulate matter may form by gas-to-particle conversion from precursor gases (e.g. nitrogen oxides, sulfur dioxide, volatile organic compounds) that stem from wood smoke, outgassing of building material, and furniture or vehicle emissions in houses with attached or built-in garages. Wear and tear also contribute to indoor particles. Small amounts of silicates, mold and pollen may exist as well.

Indoor emissions of $\mathrm{PM}_{2.5}$ have less space to dilute and disperse as compared to emissions outside. Indoor $\mathrm{PM}_{2.5}$ concentrations also depend on the duration and intensity of ventilation, number of occupants and their activity, airflow as well as pollutant dynamics like first order removal and sorptive interaction processes [4] [5]. The construction type affects both-indoor emissions from outgassing and type of ventilation (natural only, natural and mechanical). Mechanical ventilation encompasses kitchen and bathroom exhaust fans or hoods. The flow rate differs among systems depending on their purpose, size, building type and volume as well as the system's location. Natural ventilation occurs by air flow through open windows or doors. It is driven by the pressure gradients between inside and outside temperature differences and wind [6]. Natural ventilation varies with weather conditions and season. Its impact on indoor air quality also depends on outdoor air quality.

Particle loss rates by Brownian diffusion, gravitational settling, interception, and impaction vary with particle size [4]. Brownian diffusion dominates for ultrafine particles with diameters smaller than about $0.1 \mu \mathrm{m}$. Interception, impaction, and gravitational settling dominate the removal of particles exceeding this diameter [5] [7]. Due to activities by the occupants particles may re-suspend after deposition.

The non-existence of other natural air cleansing mechanisms (e.g. removal by precipitation) contributes to high indoor concentrations unless air-purifier or filter is used. A recent study showed that indoor exposure to emitted $\mathrm{PM}_{2.5}$ (per unit mass) can exceed that of exposure to outdoor emissions by two to three orders of magnitude [1].

The majority of indoor air quality studies have focused on residences in the contiguous U.S. and Europe. Only few studies exist that examined air quality in 
industrial, school [8], office or commercial buildings [1] [9] [10]. A recent study in New England revealed that homes with a woodstove had $20.6 \%$ higher $\mathrm{PM}_{2.5}$ concentrations than those without. $\mathrm{PM}_{2.5}$ concentrations were higher in homes with old stoves, non-EPA-certified stoves, and when burning wet or mixed (vs. dry) wood than those with new EPA-certified stoves burning dry wood [11]. In rural, tribal communities, especially when they are off the road network, old, pot-bellied wood stoves still exist for heating and cooking.

Studies on wildfire smoke impacts mainly focused on urban communities in highly populated areas with distinct firefighting in place [12]. Wildfires are a natural element of the landscape evolution of the Interior and typically occur between May and September in Interior Alaska. Due to the sparse population of the Eastern Interior and undeveloped road network, however, wildfires are watched and only fought actively when they might endanger historic heritage places or burn properties. This so-called "let burn policy" exposes residents to wildfire smoke-often at unhealthy concentrations-over extended periods [13] [14]. Furthermore, studies suggested that the frequency and extent of wildfire might increase in the future [15].

To assess the vulnerability of communities in the Yukon Flats, indoor aerosol concentration data were collected in various types of buildings in conjunction with simultaneous outdoor measurements in the largest community of the Yukon Flats (to ensure privacy). The objectives were to assess differences and delays between indoor and outdoor air quality, and to identify ways to reduce exposure.

\section{Experimental Design}

\subsection{Network}

To accomplish our goals, we conducted a survey of home and business construction type and heating appliances in the communities of the Yukon Flats. Based on the survey results 15 representative homes and five representative business buildings were chosen in Ft. Yukon. Fort Yukon is the largest and oldest community in the Yukon Flats (66.56667N, 145.2581W, $134 \mathrm{~m}$ ). It encompasses 583 inhabitants in 246 households. The number of people, more than quadruples in summer due to tourists and fire-fighters who are stationed there during the May to September wildfire season [13]. Fort Yukon is located on the north bank of the Yukon River in the center of the Yukon Flats.

To monitor the outdoor air quality and weather conditions, we deployed four EPA-suggested equivalent method monitors and meteorological measuring devices strategically outside the city of Ft. Yukon (Figure 1).

Aerosol indoor PM monitors were located in the five business buildings at $1.52 \mathrm{~m}(5 \mathrm{ft})$ and in the homes at $0.61 \mathrm{~m}(2 \mathrm{ft})$ and $1.52 \mathrm{~m}$ height. These heights correspond to breathing height of adults when sleeping and being up, respectively. Measurements were taken from 14 March 2019 to 30 September 2019. 


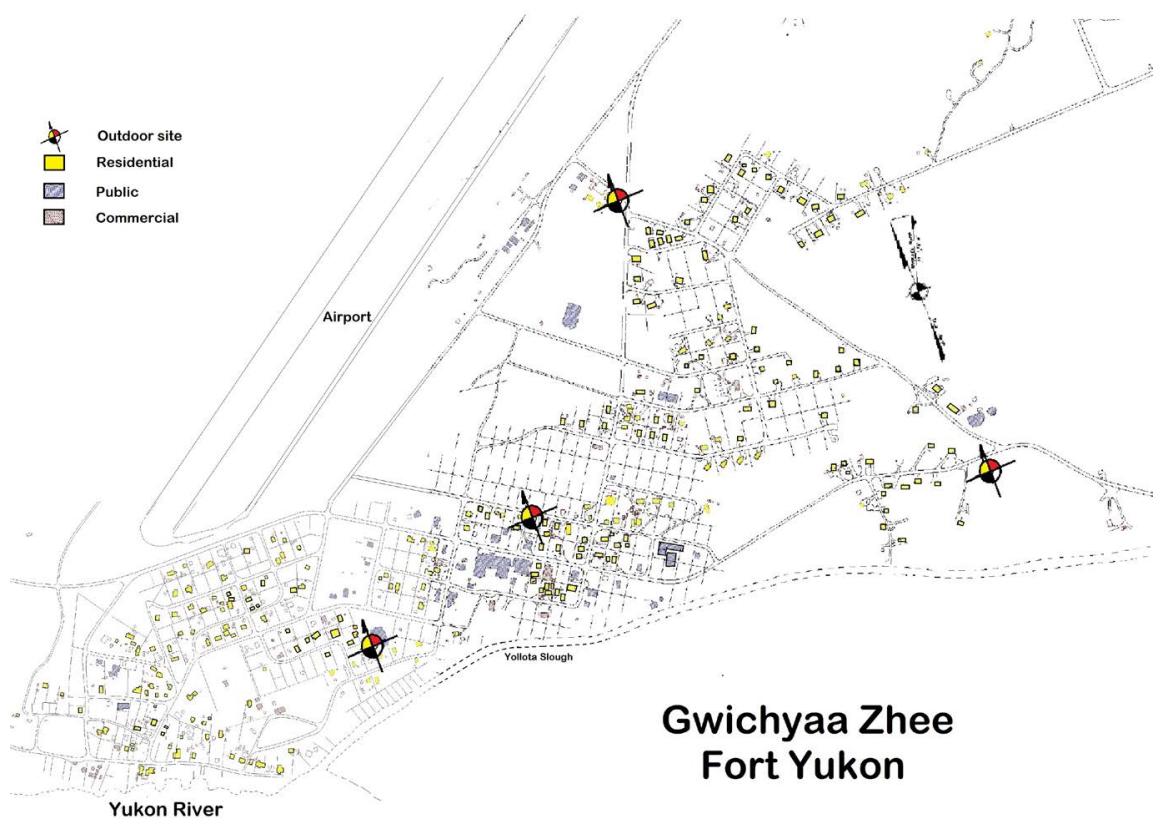

Figure 1. Map of Ft. Yukon and its vicinity to show the locations of the outdoor monitoring sites (red crosses). Note that locations of indoor monitoring sites cannot be shown for privacy reasons. Gray buildings are public buildings like school, power plant, council buildings, etc., yellow buildings are residencies. The dashed line indicates the Yukon River and Yolada slough bank. Solid lines are roads or streets.

Based on the survey two different home types-cabins and frame houses-were chosen for this study. In Ft. Yukon, cabins are a combination of regional endowed style and modern assembly changes. Frame homes are the common plywood, insulation, and tine structural types normally seen everywhere in the US in rural areas. All homes used woodstoves and furnace with temperature monitor for heating.

Office/commercial buildings with and without monitor were considered as well.

\subsection{Specifications of the Instruments}

A Met One Instruments' BAM-1022, Decagon's EM50 meteorological monitor, Davis cup anemometer, VP-4 ambient temperature/barometric pressure/relative humidity combination sensor were deployed at each of the four outdoor sites. The BAM-1022 were in an enclosed housing to protect the air intake vents from horizontally blown snow and dust, and solar radiation (Figure 2(a)). Air was taken in at $2 \mathrm{~m}$ height. BGI VSCC Very Sharp Cut Cyclone (BX-808) particle size separator was set to let only particles equal to $2.5 \mu \mathrm{m}$ or smaller to pass. The combination sensor recorded temperature, barometric pressure and relative humidity at $2 \mathrm{~m}$ height. At $5 \mathrm{~m}$ height, precipitation and total in-coming radiation were observed. The Decagon EM50 measured temperature, pressure, and relative humidity at $10 \mathrm{~m}$ height. Wind speed and direction were measured at 10 $\mathrm{m}$ height as well. Table 1 summarizes the instrument specifications. The real-time measurement interval was $5 \mathrm{~min}$ for all devices. 


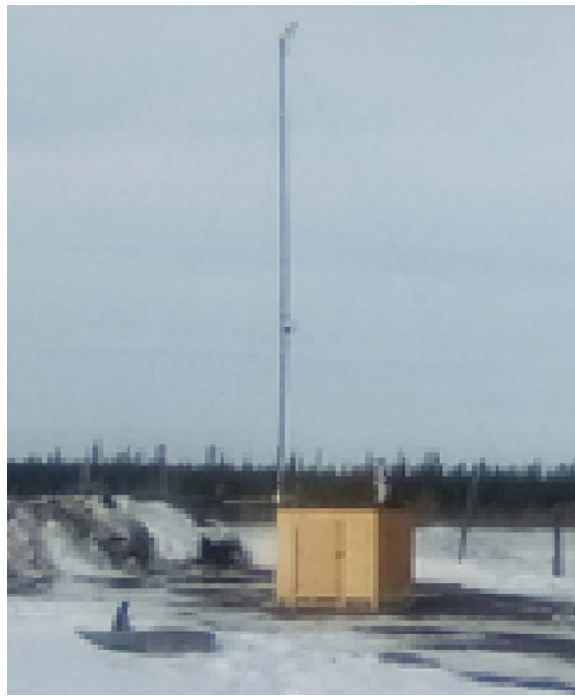

(a)

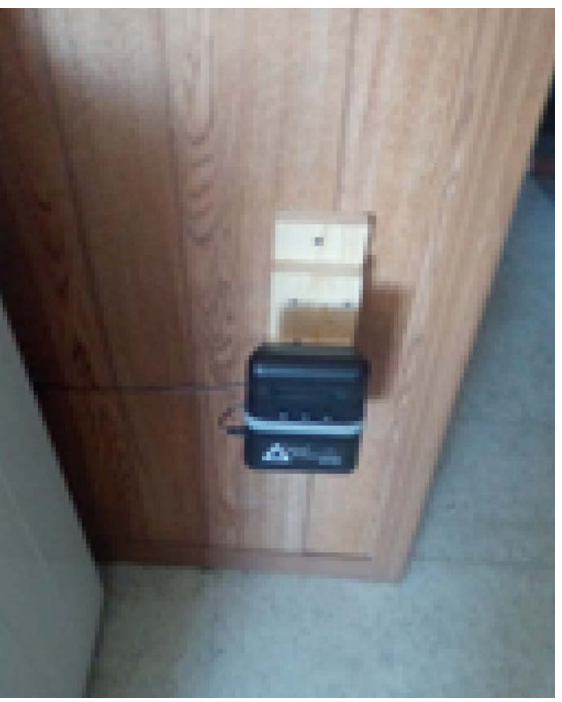

(b)

Figure 2. Photos of (a) one outdoor site and (b) the indoor monitor in the lab.

Table 1. Specifications of the deployed instruments.

\begin{tabular}{|c|c|c|c|c|}
\hline \multirow{2}{*}{ Instrument } & \multicolumn{4}{|c|}{ Specifications } \\
\hline & Observable & Range & Resolution & Accuracy \\
\hline Davis Cup & Wind direction & $>0^{\circ}$ to $360^{\circ}$ & $1^{\circ}$ & $\pm 7^{\circ}$ \\
\hline \multirow[t]{2}{*}{ Anemometer } & Wind speed & 0.9 to $78 \mathrm{~m} \cdot \mathrm{s}^{-1}$ & $0.04 \mathrm{~m} \cdot \mathrm{s}^{-1}$ & $\pm 5 \%$ \\
\hline & Pressure & 500 to $1100 \mathrm{hPa}$ & $0.01 \mathrm{hPa}$ & $\pm 0.30 \mathrm{hPa}$ \\
\hline \multirow[t]{2}{*}{ VP-4 } & Rel. humidity & $0 \%$ to $100 \%$ & $0.1 \%$ & $\pm 0.8 \%$ \\
\hline & Air temperature & $-50^{\circ} \mathrm{C}$ to $70^{\circ} \mathrm{C}$ & $0.1^{\circ} \mathrm{C}$ & $\pm 0.1^{\circ} \mathrm{C}$ \\
\hline \multirow[t]{3}{*}{ BAM-1022 } & Outdoor $\mathrm{PM}_{2.5}$ & 0 to $10000 \mu \mathrm{g} \cdot \mathrm{m}^{-3}$ & $0.1 \mu \mathrm{g} \cdot \mathrm{m}^{-3}$ & $\pm 0.1 \mu \mathrm{g} \cdot \mathrm{m}^{-3}$ \\
\hline & $\begin{array}{c}\text { PYR Solar } \\
\text { downward radiation }\end{array}$ & 0 to $1000 \mathrm{~W} \cdot \mathrm{m}^{-2}$ & $380 \mathrm{~nm}$ to $1120 \mathrm{~nm}$ & $\pm 1 \mathrm{~W} \cdot \mathrm{m}^{-2}$ \\
\hline & $\begin{array}{c}\text { ECRN-100 } \\
\text { Precipitation }\end{array}$ & collector surface $200 \mathrm{q} \cdot \mathrm{cm}^{-2}$ & $0.2 \mathrm{~mm}$ & $\pm 1 \mathrm{~mm}$ \\
\hline DC- 1700 & Indoor $\mathrm{PM}_{2.5}$ & 0 to $1000 \mu \mathrm{g} \cdot \mathrm{m}^{-3}$ & $0.1 \mu \mathrm{g} \cdot \mathrm{m}^{-3}$ & $\pm 0.1 \mu \mathrm{g} \cdot \mathrm{m}^{-3}$ \\
\hline
\end{tabular}

The Dylos DC-1700 indoor particle monitor is a highly accurate class 1 laser particle counter, and complies with 21CFR1040.10 and 11 (Figure 2(b)). The DC-1700 can display both actual particle concentrations, which relates to the International Standard (ISO) for indoor air (Table 2), as well as mass concentrations, which relates to EPA standards (Table 3). Herein, an indoor aerosol concentration of $1000 \mu \mathrm{g} \cdot \mathrm{m}^{-3}$, for instance, would correspond to 100,000 particles of 0.5 micron or smaller in diameter, and would indicate very poor air quality.

\subsection{Quality Assurance/Quality Control and Data Processing}

The data files of each of the outdoor sites were synchronized for time and combined. The same quality assurance/quality control (QA/QC) protocol as described 
Table 2. ISO for indoor air quality for particle concentrations.

\begin{tabular}{cc}
\hline Air Quality Chart $0.5 \mu \mathrm{m}$ & Small Count Reading (per ISO) \\
\hline $3000+$ & Very Poor \\
$1050-3000$ & Poor \\
$300-1050$ & Fair \\
$150-300$ & Good \\
$75-150$ & Very Good \\
$0-75$ & Excellent \\
\hline
\end{tabular}

Table 3. Mass concentration and EPA 24-h outdoor standard.

\begin{tabular}{cc}
\hline $\mathrm{PM}_{2.5}$ & Air Quality Rating (per EPA) \\
$0-12$ & Good \\
$12.1-35.4$ & Moderate \\
$35.5-55.4$ & Unhealthy for Sensitive Groups \\
$55.4-150.4$ & Unhealthy \\
$150.5-250.4$ & Very Unhealthy \\
$250.5+$ & Hazardous \\
\hline
\end{tabular}

in [13] was applied for both the indoor and outdoor observations. Missing data were tagged as such; false and/or data beyond an instrument's range were discarded and tagged as such.

\subsection{Data Analysis}

To ensure the privacy of the home and business owners, we striped the data from all information that could be used for identification (location, owner, renter, number of occupants, year of construction, etc.). In doing so, we averaged the recorded data over all measurements from homes of same construction and over all offices/commercial buildings with same heating appliance type. The indoor concentrations served to quantify the long-term means of exposure.

For all quantities, we determined the hourly, daily, monthly and seasonal means and standard deviations. We compared the 24-h means of indoor and outdoor $\mathrm{PM}_{2.5}$ concentrations to the ISO rating scales (Table 2, Table 3) and concentrations found in the literature. Daily means were also assessed using the current U.S. National Ambient Air Quality Standard (NAAQS) for 24-h average for $\mathrm{PM}_{2.5}$ of $35 \mu \mathrm{g} \cdot \mathrm{m}^{-3}$ [16] and to the World Health Organization (WHO) recommended 3-day average of $25 \mu \mathrm{g} \cdot \mathrm{m}^{-3}$ [17] that should not be exceeded. In accord with [18], the standard deviations served as an indicator of the temporal variations of $\mathrm{PM}_{2.5}$ and other quantities over a time interval of interest (hour, day, month, season).

The outdoor concentration and wind direction data at individual sites were analyzed to assess the contributions of emissions from the various sources from 
within the village and from outside.

To attribute sources, we calculated hourly $\mathrm{PM}_{2.5}$ concentration means as a function of wind direction using the WHO and EPA recommended algorithm [16] [17] [19].

To examine the relation of indoor and outdoor air quality and its dependence on the weather conditions, we averaged the meteorological and air quality data of the four outdoor $\mathrm{PM}_{2.5}$ monitors as well. The hourly means over the four outdoor $\mathrm{PM}_{2.5}$ concentrations were also used to identify surface-based inversions (SBI), their onset and dissipation as well as duration and the air flow in and out of the community following [13] [20]. These hourly means also served to examine differences in the degree of pollution as compared to indoors.

Furthermore, we calculated monthly mean diurnal courses and 24-h means of $\mathrm{PM}_{2.5}$ concentrations for the outdoors, residences at large, cabins, frame houses, office/commercial buildings as well as office/commercial buildings with and without temperature monitor. Ratios of indoor to outdoor (1/O) concentrations were determined as well.

\section{Results and Discussion}

\subsection{Emission Sources}

The National Emissions Inventory 2017 (NEI2017) reports only the annual totals of the Yukon-Koyukuk borough without distinction between the airsheds of the Yukon Flats and the Koyukuk region. Annual total emissions of the borough were 8254, 8093, 402, 6054, 1825, 15 and 1 metric tons for halocarbon (HC), carbon monoxide $(\mathrm{CO})$, nitrogen oxides $\left(\mathrm{NO}_{\mathrm{x}}\right)$, particulate matter less or equal to $10 \mu \mathrm{m}$ in diameter $\left(\mathrm{PM}_{10}\right), \mathrm{PM}_{2.5}$, sulfur oxide $\left(\mathrm{SO}_{\mathrm{x}}\right)$ and ammonia $\left(\mathrm{NH}_{3}\right)$, respectively.

In Ft. Yukon, large emission sources for $\mathrm{PM}_{2.5}$ and its precursor gases stem from burning grade-1 diesel for heating the city office buildings, corporation buildings, stores, businesses, the Tribal Council and Tribal Consortium buildings, regional health clinic and laundry-mat [13]. These buildings are all in the center of Ft. Yukon (Figure 1). Emissions vary with time of day, day of the week, time of the year, holidays and outside weather conditions. Another source for emissions of $\mathrm{PM}_{2.5}$ and its precursor gases is the biomass power plant.

Residences use furnaces burning grade-1 diesel fuel and/or woodstoves for heating in winter. Typically, wood- and diesel burning occur during the day and night, respectively. Due to the far north location sporadic heating may occur also in the other seasons. In addition, anthropogenic emissions of fine particulate matter and precursors occur from outdoor cooking of dog food and during the various subsistence seasons from smoking within the village and/or its surroundings [13] [20].

In Ft. Yukon, large vehicle fleets of private and municipal vehicles exist that use gas or diesel. Cold starts cause higher emissions [21] in the cold season (October to April) than in the warm season (May to September). Idling of vehicles 
to warm up the engine contributes to the cold and transition seasons' traffic emissions. Off-road vehicles are mostly snow mobiles and four-wheelers. Traffic emissions on the Yukon stem from boats in summer and snow mobiles in winter. Air traffic emissions stem from multiple daily scheduled flights and during the fire season from large retardant cargo carriers [13] [20]. These aircrafts burn leaded fuel.

Sources of silicate aerosols are the city road systems and dust-uptake by wind from river gravel bars [13] [20] [22].

The analysis of the wind direction data and outdoor $\mathrm{PM}_{2.5}$ concentrations confirmed the findings of [13] regarding the major contributors to local air concentrations.

Common indoor emission sources of particulate matter and its precursors are cooking, woodstoves, fur and hide tanning, fire places, outgassing of building material, carpets and furniture and in houses with built-in or attached garages, vehicle and engine emissions.

The indoor emissions vary by age of building, carpet and furniture types, type and age of heating and cooking devices, number, age and activities of household members, among other things. No emission data were recorded. Of course, the amount of indoor emissions and outdoor concentration and hence vicinity to outdoor emission sources as well as the air exchange between inside and outside air affect indoor concentrations. Measurements at two schools located in Hanoi, Vietnam, for instance, revealed indoor average concentrations of $\mathrm{PM}_{2.5}$ and $\mathrm{PM}_{10}$ of $49.4 \mu \mathrm{g} \cdot \mathrm{m}^{-3}$ and $59.7 \mu \mathrm{g} \cdot \mathrm{m}^{-3}$ in one neighborhoods and $7.9 \mu \mathrm{g} \cdot \mathrm{m}^{-3}$ and 10.8 $\mu \mathrm{g} \cdot \mathrm{m}^{-3}$ in another, respectively [23]. Similarly, in our Ft. Yukon campaign, outdoor and indoor air quality also showed differences dependent on the vicinity to major emissions sources. Smoking and cooking were found to increase indoor and kitchen $\mathrm{PM}_{2.5}$ concentrations rapidly to $1280 \mu \mathrm{g} \cdot \mathrm{m}^{-3}$ and $3000 \mu \mathrm{g} \cdot \mathrm{m}^{-3}$, respectively [24].

\subsection{Meteorological Conditions}

Daily means of $10 \mathrm{~m}$ height wind speed rarely exceeded $5 \mathrm{~m} \cdot \mathrm{s}^{-1}$ (Figure 3(a)). At $10 \mathrm{~m}$ height, daily means of relative humidity varied between $33 \%$ and $96 \%$ and were $59 \%$ on average over all days. Daily means of relative humidity at $2 \mathrm{~m}$ height ranged between $32 \%$ and $95 \%$, but were on average around 57\% (Figure $3(\mathrm{a}))$. At this height, daily mean temperatures were between $-11^{\circ} \mathrm{C}$ and $24.5^{\circ} \mathrm{C}$ (Figure 3(a)). At $10 \mathrm{~m}$ height, these values were $-11.4^{\circ} \mathrm{C}$ and $24.9^{\circ} \mathrm{C}$, respectively. Total accumulated solar downward radiation varied between $80 \mathrm{~kW} \cdot \mathrm{m}^{-2} \cdot \mathrm{h}^{-1}$ and $1247 \mathrm{~kW} \cdot \mathrm{m}^{-2} \cdot \mathrm{h}^{-1}$ depending on the day of year and atmospheric conditions including cloudiness and aerosol optical depth (see Figure 3(b)).

\subsection{Surface-Based Temperature Inversions}

Following [20], we used hourly means of the outdoor temperature measurements at $10 \mathrm{~m}$ and $2 \mathrm{~m}$ height as an indicator for the occurrence of surface-based 


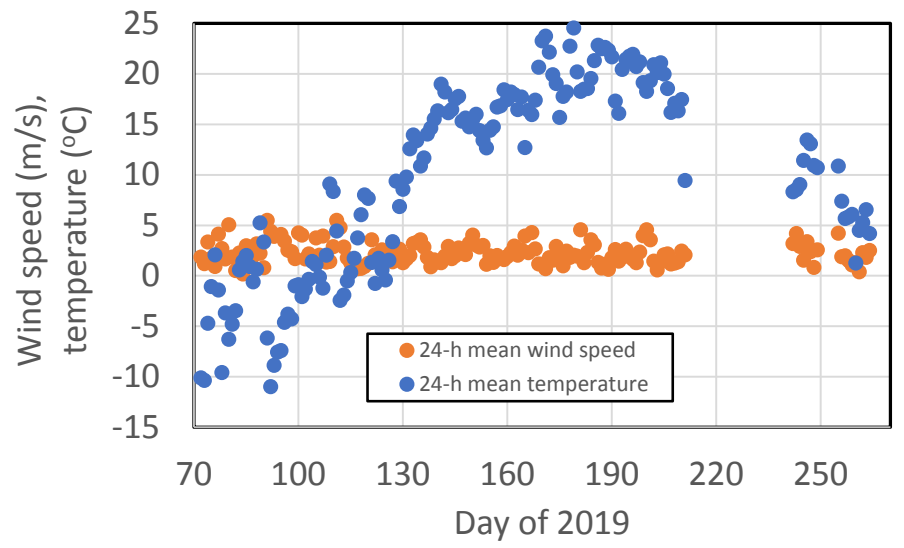

(a)

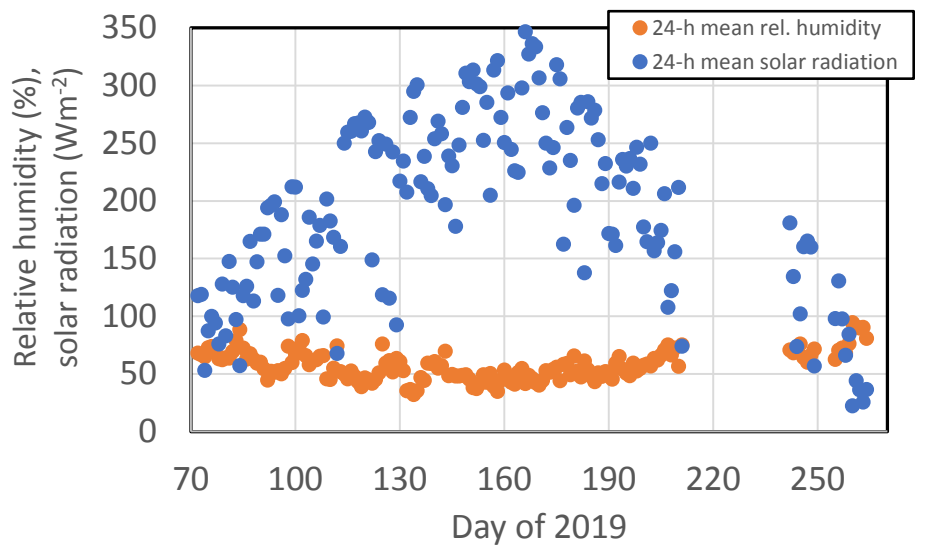

(b)

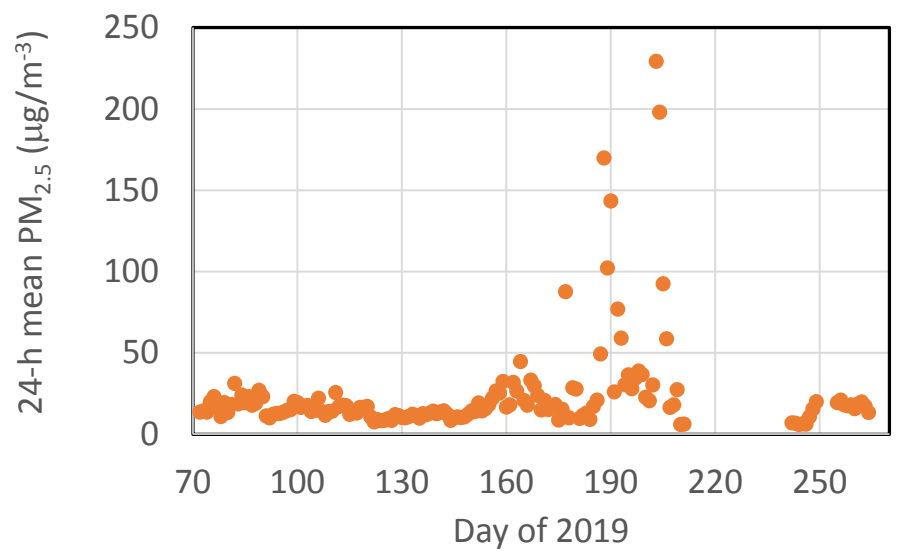

(c)

Figure 3. Daily mean outdoor meteorological and air quality conditions during the campaign averaged over the four sites: (a) $2 \mathrm{~m}$ height temperature and $10 \mathrm{~m}$ height wind speed, (b) $2 \mathrm{~m}$ height relative humidity and solar radiation, and (c) outdoor $\mathrm{PM}_{2.5}$ conditions.

temperature inversions during the respective days of the study. For each day the start and end time as well as the duration of the surface inversion were determined (e.g. Figure 4). 


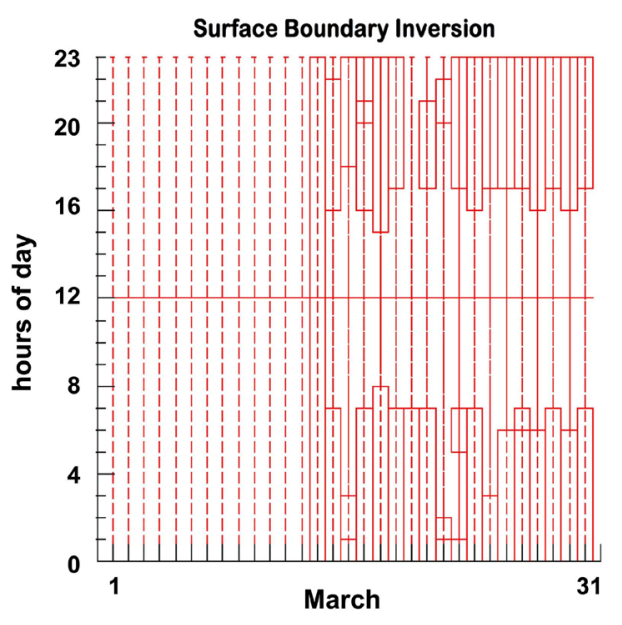

(a)

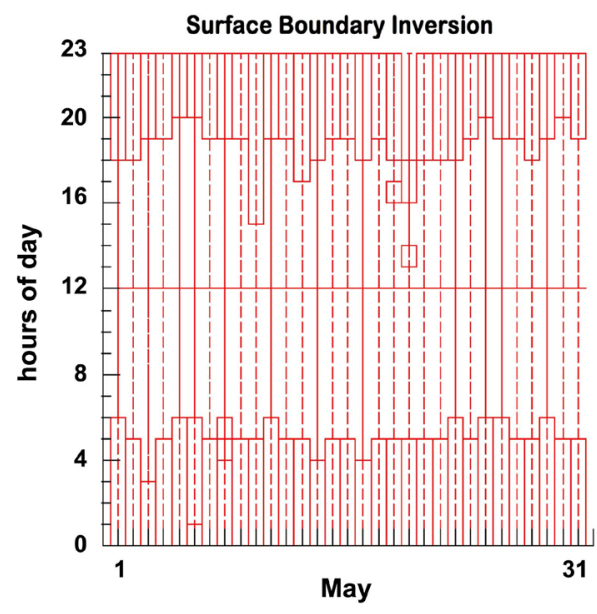

(c)

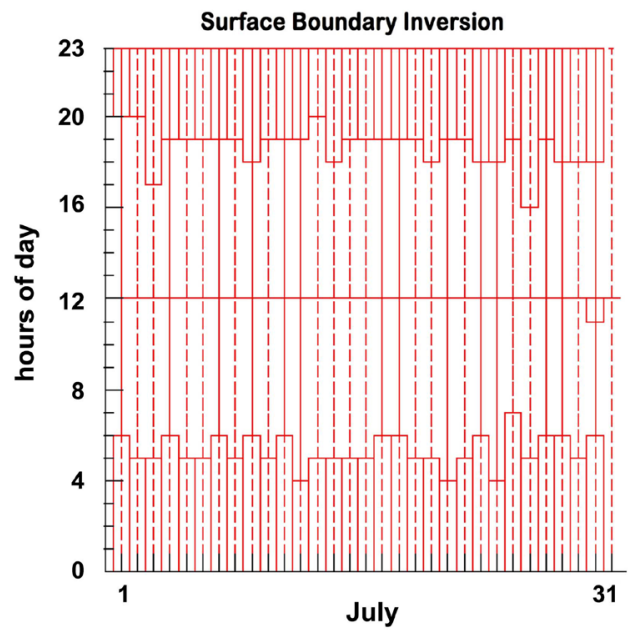

(e)

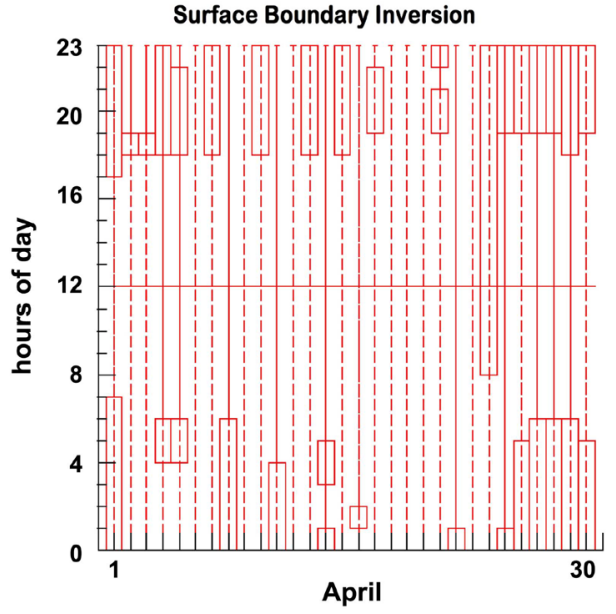

(b)

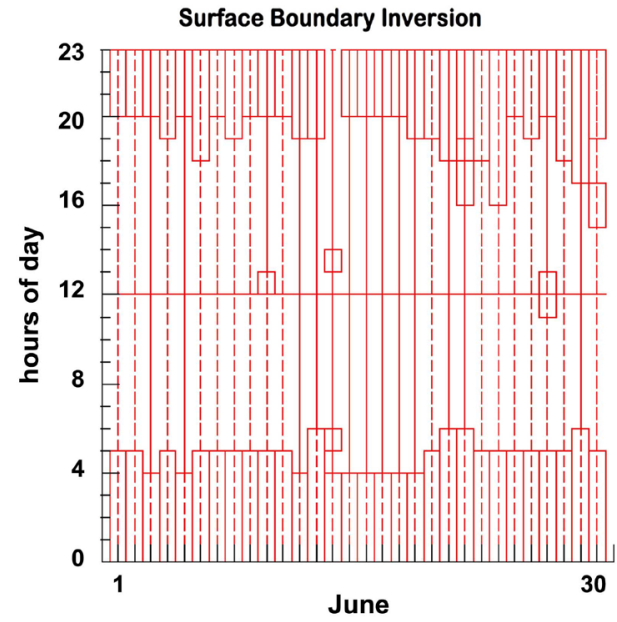

(d)

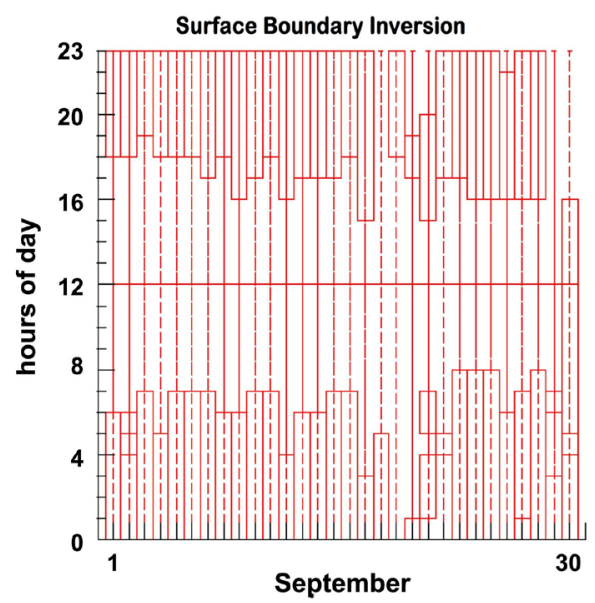

(f)

Figure 4. Daily local times with (bars) and without inversions at Ft. Yukon as obtained from the hourly averages of $10 \mathrm{~m}$ and $2 \mathrm{~m}$ temperatures differences over all four outdoor sites for (a) March, (b) April, (c) May, (d) June, (e) July and (f) September. Days without bars indicate missing data. August is not shown due to the high amount of missing data. 
All days with complete temperature data had surface-based inversion (e.g. Figure 4). The duration throughout a day varied from March to September. The majority of all SBI occurred through the late night and early morning, local time. Some multiday SBI occurred in the shoulder season. Occasionally, more than one SBI formed per day. Durations of SBI were typically shorter in April than in the other months due to increased wind speed. Furthermore, the onset of melting led to differential heating and convection broke the SBI.

\subsection{Exposure to $\mathrm{PM}_{2.5}$}

\subsubsection{Outdoor Air Quality}

The daily data of hourly means of temperatures and the derived onset, dissipation and duration of inversions were utilized to separate the measured outdoor $\mathrm{PM}_{2.5}$ concentrations into two categories, namely those (a) occurring during a surface-based inversion (SBI) event and (b) those occurring during hours without an SBI (Table 4).

Following the EPA guidance, we calculated the 24-h mean outdoor $\mathrm{PM}_{2.5}$ concentrations from hourly mean concentrations. To assess the exposure on a monthly basis we averaged over the daily 24 -h means of the respective month $\left(2^{\text {nd }}\right.$ column in Table 4$)$. Since inversions only existed for parts of the day (see e.g. Figure 4) and started or ended not necessarily to the full hour, means for times with and without inversions were calculated for each month based on the 5-min mean raw data that were kept after the QA/QC. These monthly means for times with and without the presence of SBI are up to about factor 2 higher than the monthly means calculated from 24-h means calculated in accord with the NAAQS (Table 4).

The difference between the monthly mean of 24-h means and the monthly means for times with or without inversions in the following tables is that the latter two cover not the full amount of hours of the months. This means that they are expressed in terms of means for the times with or without inversions. The monthly mean of 24-h average $\mathrm{PM}_{2.5}$ concentrations is given by

$$
\overline{\mathrm{PM}_{2.5}}=\frac{\Delta t_{\mathrm{no}} \overline{\mathrm{PM}_{2.5, \mathrm{no}}}+\Delta t_{\mathrm{SBI}} \overline{\mathrm{PM}_{2.5, \mathrm{SBI}}}}{\Delta t_{\mathrm{SBI}}+\Delta t_{\mathrm{no}}}
$$

where $\overline{\mathrm{PM}_{2.5, \mathrm{SBI}}}$ and $\overline{\mathrm{PM}_{2.5, \mathrm{no}}}$ are the concentrations during times with and without inversions, respectively. Furthermore, $\Delta t_{\mathrm{SBI}} /\left(\Delta t_{\mathrm{SBI}}+\Delta t_{\mathrm{no}}\right)$ and $\Delta t_{\mathrm{no}} /\left(\Delta t_{\mathrm{SBI}}\right.$ $\left.+\Delta t_{\mathrm{no}}\right)$ are the ratios of the times with and without inversions to the time in the month. Note that $\Delta t_{\mathrm{SBI}}=1-\Delta t_{\mathrm{no}}$.

On average, outdoor air quality improved from March to May (Figure 5). Due to increasing air temperatures emissions from heating went down as spring progressed. After the onset of the wildfire season (end of May), ambient monthly $\mathrm{PM}_{2.5}$ concentrations increased in June (Table 4). Also wind speeds increased as compared to the earlier months and picked up dusts from unpaved roads and the Yukon and Porcupine riverbanks. Nevertheless, March to June monthly mean $\mathrm{PM}_{2.5}$ concentrations remained below $25 \mu \mathrm{g} \cdot \mathrm{m}^{-3}$. Monthly mean outdoor 
Table 4. Monthly means and their standard deviations of daily 24-h mean outdoor $\mathrm{PM}_{2.5}$ concentrations averaged over all four sites, and means and standard deviations calculated from all hours without (no inversion) and all hours with surface based inversions (SBI) using data from all four sites.

\begin{tabular}{cccc}
\hline \multirow{2}{*}{ Month } & \multicolumn{2}{c}{ Monthly mean $\mathrm{PM}_{2.5}$ concentrations and standard deviations $\left(\mu \mathrm{g} \cdot \mathrm{m}^{-3}\right)$} \\
\cline { 2 - 4 } & Outdoor & No inversion outdoor & SBI outdoor \\
\hline March & $19.1 \pm 5.2$ & $30.3 \pm 3.0$ & $39.4 \pm 3.8$ \\
April & $15.8 \pm 3.7$ & $26.0 \pm 2.5$ & $39.4 \pm 4.2$ \\
May & $11.3 \pm 2.2$ & $13.8 \pm 1.3$ & $22.5 \pm 1.0$ \\
June & $23.9 \pm 14.6$ & $35.8 \pm 8.4$ & $46.4 \pm 5.1$ \\
July & $55.3 \pm 59.2$ & $58.4 \pm 13.2$ & $100.4 \pm 17.0$ \\
August & $5.4 \pm 2.3$ &.-- &.-- \\
September & $14.8 \pm 5.7$ & $24.6 \pm 5.8$ & $27.8 \pm 3.9$ \\
\hline
\end{tabular}

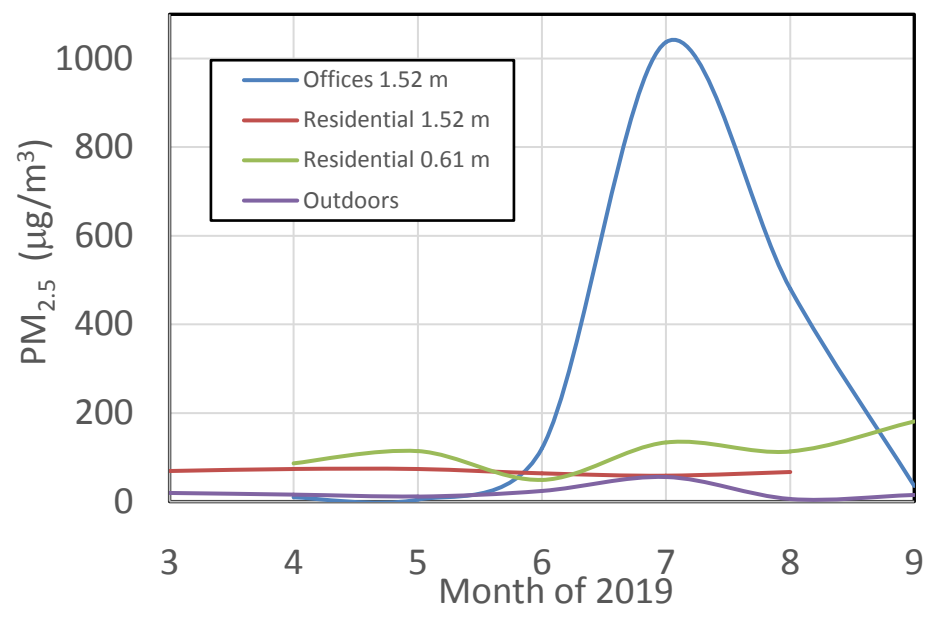

(a)

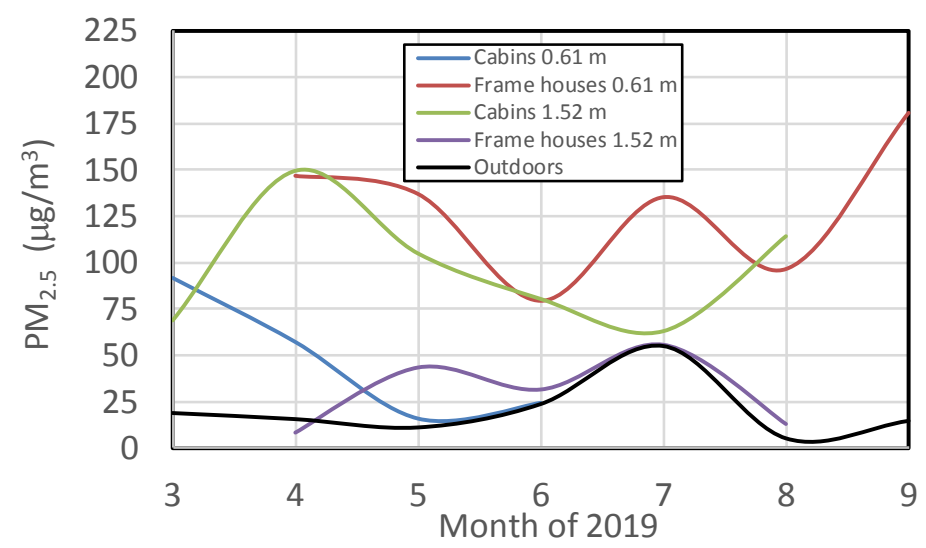

(b)

Figure 5. Temporal evolution of monthly mean $\mathrm{PM}_{2.5}$ concentration.

$\mathrm{PM}_{2.5}$ concentrations reached $55.3 \mu \mathrm{g} \cdot \mathrm{m}^{-3}$ in July due to wildfires (Table 4). This means the 24-h NAAQS was exceeded and led to unhealthy for sensitive groups 
to hazardous conditions on various days. In August, the rain season set on for which outdoor air quality improved. In September, outdoor air quality slightly decreased because decreasing air temperatures caused emissions from heating. Furthermore, inversion durations increased (Figure 4).

On average, monthly mean $\mathrm{PM}_{2.5}$ concentrations were higher during surface-based inversions than at other times (Table 4). During times with and without SBI, $\mathrm{PM}_{2.5}$ concentrations decreased from March to May as less heating was need because of increasing outdoor temperatures. In June, the wildfire season set on and led to increases in concentration during both SBIs and inversion-free times. Concentrations during time with and without inversions differed least in September $\left(3.2 \mu \mathrm{g} \cdot \mathrm{m}^{-3}\right)$ followed by May $\left(8.7 \mu \mathrm{g} \cdot \mathrm{m}^{-3}\right)$. The difference was largest $\left(42.0 \mu \mathrm{g} \cdot \mathrm{m}^{-3}\right)$ in July (cf. Table 5 , Table 6$)$ which can be explained by advection of wildfire smoke.

Over the timeframe of available data, the US NAAQS of $35 \mu \mathrm{g} \cdot \mathrm{m}^{-3}$ for the $24-\mathrm{h}$ mean was exceeded nearly $45 \%$ of the time. The WHO recommended $24 \mathrm{~h}$-value of $25 \mu \mathrm{g} \cdot \mathrm{m}^{-3}$ not to be exceeded for three consequent days was violated as well.

Table 5. Means of baselines of indoor $\mathrm{PM}_{2.5}$ concentration values at $0.61 \mathrm{~m}$ height averaged over all hours without (no inversion) and all hours with surface based inversions (SBI) averaged over all residences, cabins and frame houses within a month.

\begin{tabular}{ccccccc}
\hline & \multicolumn{6}{c}{ Monthly mean $\mathrm{PM}_{2.5}$ concentrations and standard deviations $\left(\mu \mathrm{g} \cdot \mathrm{m}^{-3}\right)$} \\
\cline { 2 - 7 } Month & $\begin{array}{c}\text { Residences no } \\
\text { inversion }\end{array}$ & Residences SBI & $\begin{array}{c}\text { Cabin no } \\
\text { inversion }\end{array}$ & Cabin SBI & $\begin{array}{c}\text { Frame house } \\
\text { no inversion }\end{array}$ & $\begin{array}{c}\text { Frame house } \\
\text { SBI }\end{array}$ \\
\hline April & $265.4 \pm 56.6$ & $90.9 \pm 28.9$ & $173.1 \pm 433.7$ & $63.5 \pm 16.8$ & $488.5 \pm 109.1$ & $143.0 \pm 63.2$ \\
May & $310.7 \pm 56.1$ & $237.7 \pm 49.4$ & $50.30 \pm 8.5$ & $42.8 \pm 10.7$ & $296.4 \pm 67.5$ & $381.1 \pm 68.4$ \\
June & $136.4 \pm 24.5$ & $79.0 \pm 14.5$ & $42.8 \pm 10.7$ & $32.3 \pm 4.1$ & $137.2 \pm 29.7$ & $218.6 \pm 47.1$ \\
July & $415.7 \pm 65.1$ & $259.7 \pm 41.0$ & $80.7 \pm 22.35$ & $31.9 \pm 0.0$ & $259.3 \pm 41.1$ & $415.5 \pm 65.2$ \\
August & $459.9 \pm 95.4$ &.-- &.-- &.-- &.-- & $459.9 \pm 95.4$ \\
September & $488.8 \pm 117.5$ & $266.8 \pm 73.5$ &.-- &.-- & $488.8 \pm 117.5$ & $266.8 \pm 73.5$ \\
\hline
\end{tabular}

Note -.- indicates no data.

Table 6. Monthly means of baselines of indoor 24-h $\mathrm{PM}_{2.5}$ concentration values at $1.52 \mathrm{~m}$ averaged over all hours without (no inversion) and all hours with surface based inversions (SBI) and their spatial standard deviations for various types of residences.

\begin{tabular}{|c|c|c|c|c|c|c|c|c|}
\hline \multirow[b]{2}{*}{ Month } & \multicolumn{8}{|c|}{ Monthly mean $\mathrm{PM}_{2.5}$ concentrations and standard deviations $\left(\mu \mathrm{g} \cdot \mathrm{m}^{-3}\right)$} \\
\hline & $\begin{array}{l}\text { Residences no } \\
\text { inversion }\end{array}$ & Residences SBI & $\begin{array}{l}\text { Frame houses } \\
\text { no inversions }\end{array}$ & $\begin{array}{c}\text { Frame houses } \\
\text { SBI }\end{array}$ & $\begin{array}{l}\text { Cabins no } \\
\text { inversion }\end{array}$ & Cabins SBI & $\begin{array}{l}\text { Office/commercial } \\
\text { buildings no } \\
\text { inversion }\end{array}$ & $\begin{array}{c}\text { Office/ } \\
\text { commercial } \\
\text { buildings SBI }\end{array}$ \\
\hline April & $123.1 \pm 37.6$ & $256.3 \pm 53.8$ & $226.6 \pm 31.4$ & $491.3 \pm 56.5$ & $2.3 \pm 1.0$ & $28.3 \pm 6.6$ & $28.7 \pm 9.0$ & $5.2 \pm 1.8$ \\
\hline May & $143.9 \pm 14.9$ & $228.4 \pm 31.2$ & $214.6 \pm 32.8$ & $325.9 \pm 47.9$ & $5.6 \pm 0.8$ & $137.7 \pm 15.7$ & $5.6 \pm 0.8$ & $12.4 \pm 1.5$ \\
\hline June & $123.7 \pm 12.4$ & $197.0 \pm 16.6$ & $153.1 \pm 16.6$ & $244.5 \pm 21.2$ & $54.5 \pm 9.1$ & $89.7 \pm 13.6$ & $227.0 \pm 122.4$ & $351.2 \pm 156.0$ \\
\hline July & $98.7 \pm 10.0$ & $168.6 \pm 21.4$ & $90.8 \pm 13.0$ & $186.1 \pm 26.6$ & $104.0 \pm 12.0$ & $170.3 \pm 24.0$ & $1677.5 \pm 357.0$ & $3390.9 \pm 851.8$ \\
\hline August &.-- & $277.2 \pm 57.9$ &.-- & $425.4 \pm 54.0$ &.-- & $51.7 \pm 8.2$ &.-- & $4019.7 \pm 983.0$ \\
\hline
\end{tabular}

Note -.- indicates no data available. 
When looking at hourly means, $\mathrm{PM}_{2.5}$ concentrations were higher than $25 \mu \mathrm{g} \cdot \mathrm{m}^{-3}$ nearly $91 \%$ of the time during SBI and about $80 \%$ of the time when no SBI existed at Ft. Yukon. During the 2017 strong fire season in the Yukon Flats [13], 5-min mean outdoor concentrations were occasionally a magnitude or more, higher than the hourly means. The maximum hourly mean $\mathrm{PM}_{2.5}$ concentrations over all four sites in March to September 2019 were $71.5 \mu \mathrm{g} \cdot \mathrm{m}^{-3}, 79.8 \mu \mathrm{g} \cdot \mathrm{m}^{-3}$, $63.6 \mu \mathrm{g} \cdot \mathrm{m}^{-3}, 289.3 \mu \mathrm{g} \cdot \mathrm{m}^{-3}, 792.3 \mu \mathrm{g} \cdot \mathrm{m}^{-3}, 22.8 \mu \mathrm{g} \cdot \mathrm{m}^{-3}$, and $66.7 \mu \mathrm{g} \cdot \mathrm{m}^{-3}$, respectively. Outdoor air quality was on average better than in the record fire season of 2017 (cf. [13]).

\subsubsection{Indoor Air Quality}

On average over all indoor sites, a diurnal course can be detected in office/commercial buildings and at both heights for residences (Figure 6). Typically, indoor concentrations were higher during the day than at night which broadly coincides times of no SBI and with SBI (Table 5, Table 6). This finding is expected as people move around in their residences thereby re-suspending particles into the air that had already settled on the floor or other surfaces. Various daytime activities like cooking, smoking or feeding of woodstove could lead

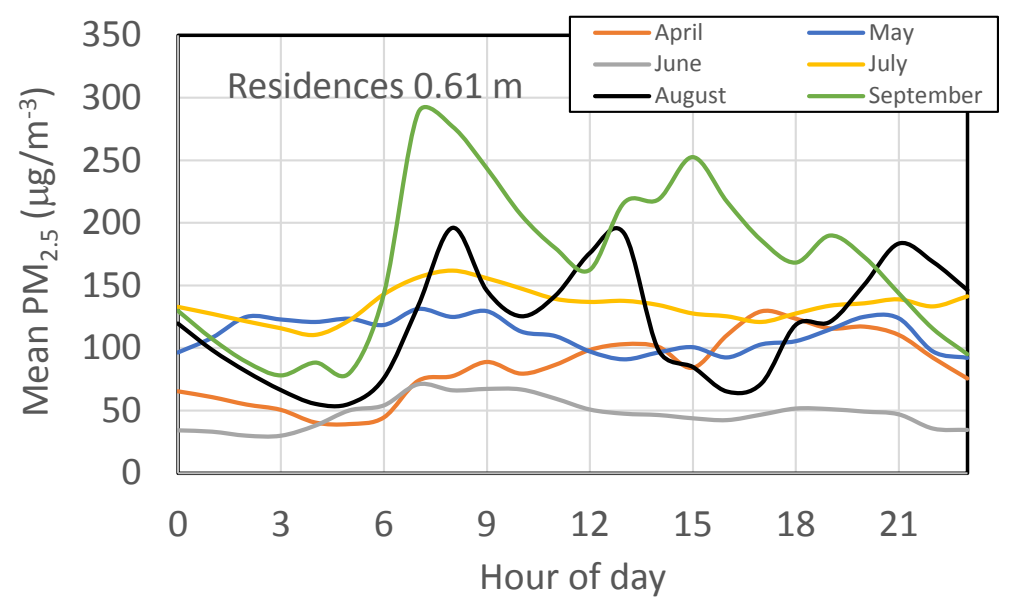

(a)

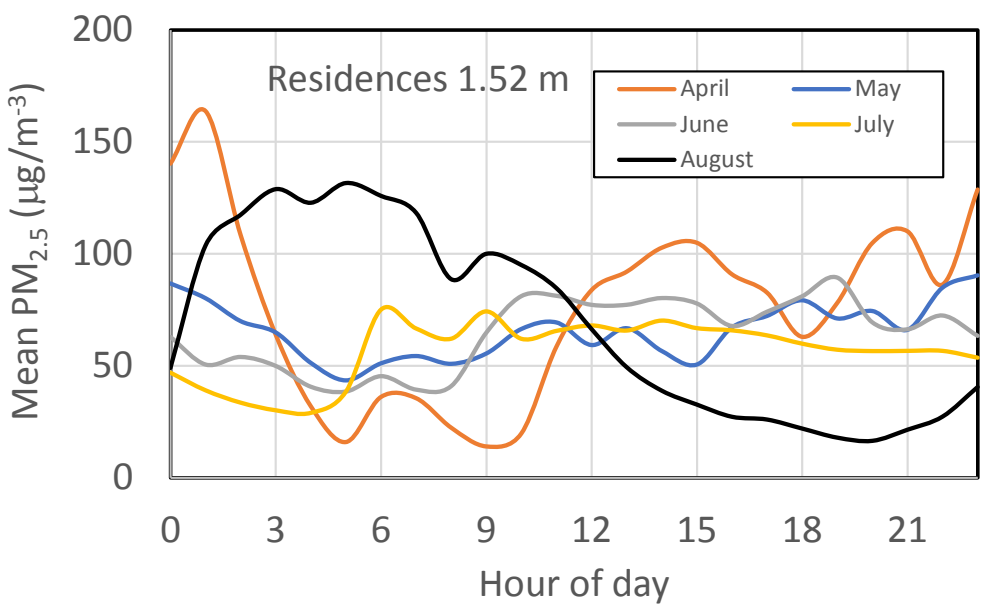

(b) 


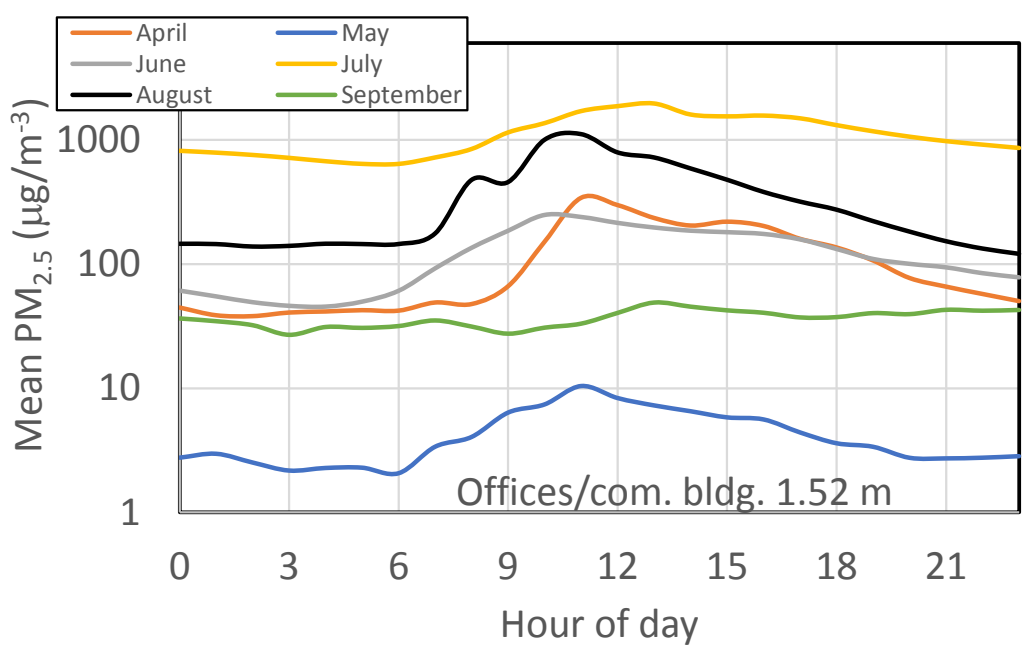

(c)

Figure 6. Temporal evolution of monthly mean diurnal course of $\mathrm{PM}_{2.5}$ concentrations.

to notable emissions of particles. In late June and July, mosquitoes become an annoyance in the Yukon Flats and are fought with mosquito pics. Mosquito pics contribute to $\mathrm{PM}_{2.5}$ concentrations in June, July and August (JJA). These activities cannot be readily controlled nor documented due to privacy issues as well as indigenous cultural distrust of being monitored.

In residences, indoor monthly mean concentrations at $0.61 \mathrm{~m}$ were lowest in June and highest in July (Table 7). Indoor concentrations at $1.52 \mathrm{~m}$ were lowest in July and highest in April and May. On average over all residences, indoor concentrations were higher at $0.61 \mathrm{~m}$ than at $1.52 \mathrm{~m}$ height (e.g. Figure 6(a)). Averaged over all residencies, monthly mean $\mathrm{PM}_{2.5}$ concentrations were 12.5 $\mu \mathrm{g} \cdot \mathrm{m}^{-3}, 40.1 \mu \mathrm{g} \cdot \mathrm{m}^{-3}, 75.3 \mu \mathrm{g} \cdot \mathrm{m}^{-3}$, and $46.1 \mu \mathrm{g} \cdot \mathrm{m}^{-3}$ higher at $0.61 \mathrm{~m}$ than at $1.52 \mathrm{~m}$ in April, May July and August, respectively. This distribution can be partly explained by gravitational settling. The hourly mean values at those heights showed weak correlation (21\%). These findings mean that exposure to high concentrations was on average over all residences higher when laying down than when standing or walking around (cf. Table 7).

The exposure at both levels was higher than the median of $6.65 \mu \mathrm{g} \cdot \mathrm{m}^{-3}$ found by [11] for households with woodstoves in New England. The values of the lower and upper range of mean hourly indoor $\mathrm{PM}_{2.5}$ concentrations (Figure 6) were lower than the 112 - $416 \mu \mathrm{g} \cdot \mathrm{m}^{-3}$ observed by [25] in homes in Beijing, China in winter. $\mathrm{PM}_{2.5}$ concentrations in office/commercial buildings in Ft. Yukon were on average very unhealthy for some hours on a daily basis in June and August and were even hazardous most of July. Exposure of employees, clients and customer was much higher than found for these groups in other places. Measurements in an office building in Guangzhou, China, for instance, showed only 3\% and $1 \%$ of the time very unhealthy and hazardous condition in JJA [10]. In Dublin, Ireland, indoor $\mathrm{PM}_{2.5}$ concentrations during working hours were typically below $25 \mu \mathrm{g} \cdot \mathrm{m}^{-3}$ with highest values in naturally ventilated shops [9]. 
Table 7. Monthly means of baselines of indoor $\mathrm{PM}_{2.5}$ concentration values averaged over all days, all hours and their standard deviations.

\begin{tabular}{|c|c|c|c|c|c|c|c|c|c|}
\hline \multirow[b]{2}{*}{ Month } & \multicolumn{9}{|c|}{ Monthly mean $\mathrm{PM}_{2.5}$ concentrations and standard deviations $\left(\mu \mathrm{g} \cdot \mathrm{m}^{-3}\right)$} \\
\hline & $\begin{array}{c}\text { Residences at } \\
0.61 \mathrm{~m}\end{array}$ & $\begin{array}{c}\text { Cabins at } \\
0.61 \mathrm{~m}\end{array}$ & $\begin{array}{c}\text { Frame houses } \\
\text { at } 0.61 \mathrm{~m}\end{array}$ & $\begin{array}{c}\text { Residences at } \\
1.52 \mathrm{~m}\end{array}$ & $\begin{array}{c}\text { Cabins at } \\
1.52 \mathrm{~m}\end{array}$ & $\begin{array}{c}\text { Frame houses } \\
\text { at } 1.52 \mathrm{~m}\end{array}$ & $\begin{array}{c}\text { Office/ } \\
\text { commercial } \\
\text { buildings }\end{array}$ & $\begin{array}{c}\text { Office/ } \\
\text { commercial } \\
\text { buildings } \\
\text { monitor }\end{array}$ & $\begin{array}{c}\text { Office/ } \\
\text { commercial } \\
\text { buildings no } \\
\text { monitor }\end{array}$ \\
\hline April & $86.1 \pm 66.9$ & $57.3 \pm 39.0$ & $146.8 \pm 95.2$ & $73.6 \pm 71.3$ & $8.3 \pm 6.0$ & $149.4 \pm 46.0$ & $9.8 \pm 10.3$ & $12.5 \pm 20.5$ & $7.3 \pm 2.8$ \\
\hline May & $113.6 \pm 107.4$ & $16.1 \pm 7.9$ & $137.0 \pm 129.2$ & $73.5 \pm 51.0$ & $43.5 \pm 20.5$ & $104.8 \pm 73.1$ & $4.4 \pm 2.6$ & $4.9 \pm 3.0$ & $4.8 \pm 3.4$ \\
\hline June & $48.8 \pm 44.4$ & $24.6 \pm 15.3$ & $79.3 \pm 85.0$ & $63.2 \pm 31.5$ & $31.6 \pm 23.4$ & $80.3 \pm 35.9$ & $120.1 \pm 266.0$ & $8.6 \pm 8.5$ & $1285.1 \pm 1097.3$ \\
\hline July & $133.5 \pm 121.9$ &.-- & $135.3 \pm 121.6$ & $58.2 \pm 40.1$ & $55.8 \pm 45.3$ & $62.9 \pm 40.8$ & $1036.7 \pm 1412.0$ & $41.7 \pm 38.3$ & $4834.4 \pm 5136.5$ \\
\hline August & $113.1 \pm 78.6$ &.-- & $96.4 \pm 53.8$ & $66.9 \pm 59.7$ & $13.0 \pm 6.1$ & $114.1 \pm 40.4$ & $480.1 \pm 343.2$ & $7.4 \pm 7.2$ & $982.0 \pm 721.5$ \\
\hline
\end{tabular}

Note -.- indicates no data available.

\subsubsection{Indoor vs. Outdoor Air Quality}

Indoor $\mathrm{PM}_{2.5}$ concentrations were influenced not only by continuous and temporal indoor emission sources, the residents' activities and the degree of mixing related to the residents' motions, but also by exchange between inside and outside air.

In contrast to all other months, June concentrations were lower $\left(14.4 \mu \mathrm{g} \cdot \mathrm{m}^{-3}\right)$ at $0.61 \mathrm{~m}$ than $1.52 \mathrm{~m}$, which can be explained by transport of polluted air from nearby wildfires into the community. Typically, in wildfire smoke, $\mathrm{PM}_{2.5}$ concentrations decrease from the maximum values towards the ground as well as with height. Consequently, outdoor air has higher concentrations at the heights of vents than at the gaps between doors and the floor.

In comparison to outdoors, indoor concentrations of $\mathrm{PM}_{2.5}$ were usually much larger in magnitude (cf. Tables 4-6). Monthly mean ratios of indoor to outdoor concentrations (I/O) in residences were 4.8, 5.3 and 12.2 at $0.61 \mathrm{~m}$ in March, April and September, respectively. Ratios were lowest in May, June and July with 1.4, 2.0 and 2.4, respectively. In August, I/O reached its maximum of 21. In August, the increased humidity and rainfall scavenged particles from the air thereby reducing outdoor concentrations while indoor emissions accumulated in empty homes. The increased humidity also leads to swelling of particles. This means $\mathrm{PM}_{2.5}$ concentrations may decrease, when the grown particles exceed $2.5 \mu \mathrm{m}$ in diameter. The high I/O ratios can be explained by indoor emissions from wood burning for cooking and heating, recreational smoking and use of mosquito pics. In Guangzhou and Dublin, for instance, I/O were below 1 [9] [25].

In the analysis of the impact of inversions on indoor concentrations, the question of air exchange arises. To compare indoor and outdoor concentrations of $\mathrm{PM}_{2.5}$ during times with and without SBI the temporal lag between indoor and outdoor concentrations has to be determined first. We applied a lag-time correlation method [26] at various temporal lags using the means over the hourly outdoor concentrations and those averaged over all hourly indoor concentrations as input data. The method revealed a maximum correlation for a lag-time 
of 1-hour and 2 hours for residences at $0.61 \mathrm{~m}$ and $1.52 \mathrm{~m}$ heights (e.g. Figure 7 ), respectively. It showed a time-lag of 1 hour for office/commercial buildings.

When people are not home in their residents, the floor to door gaps, and other interior-to-exterior connections (e.g. cooking hoods, vents) have a greater influence at floor levels where air settles and is cooler than at $1.52 \mathrm{~m}$. The $1.52 \mathrm{~m}$ level has a longer lag-time due to dead air and diffusion time.

Based on these findings and the determined onset and ending times of the SBIs within each 24-hour period (e.g. Figure 4), we adjusted the timing of indoor concentrations to account for the lag-time for the residences at both heights and the office/commercial buildings. Doing so synchronized the indoor concentrations with that outdoors for times with and without inversions.

On average over all residencies, indoor concentrations were higher during times without inversions than during SBIs at $0.61 \mathrm{~m}$ height in March, April and September (Table 5). From May to July, indoor concentrations at $0.61 \mathrm{~m}$ height were lower during times without inversion than during times with inversions. Averaged over the few available March days and all residences, the means were

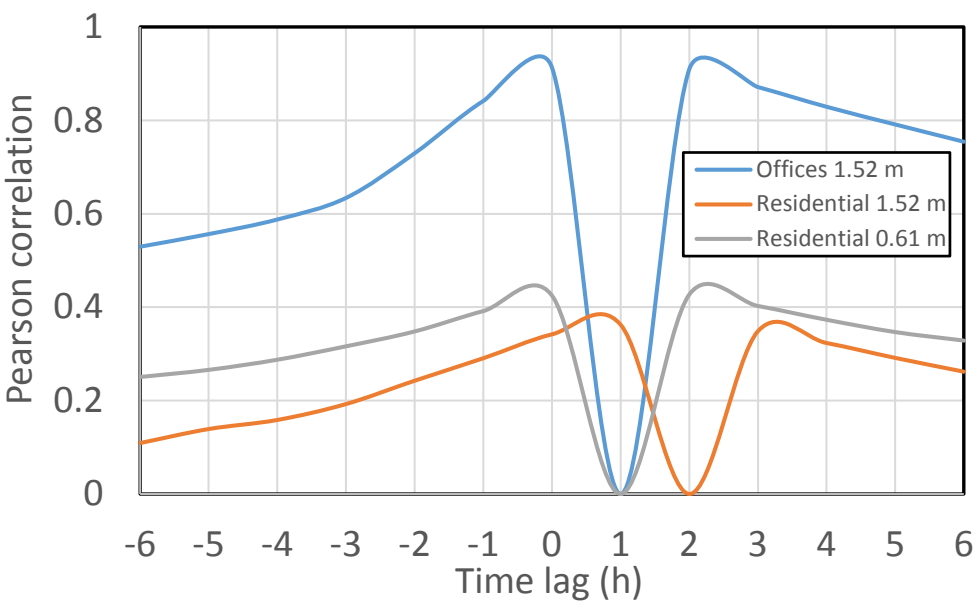

(a)

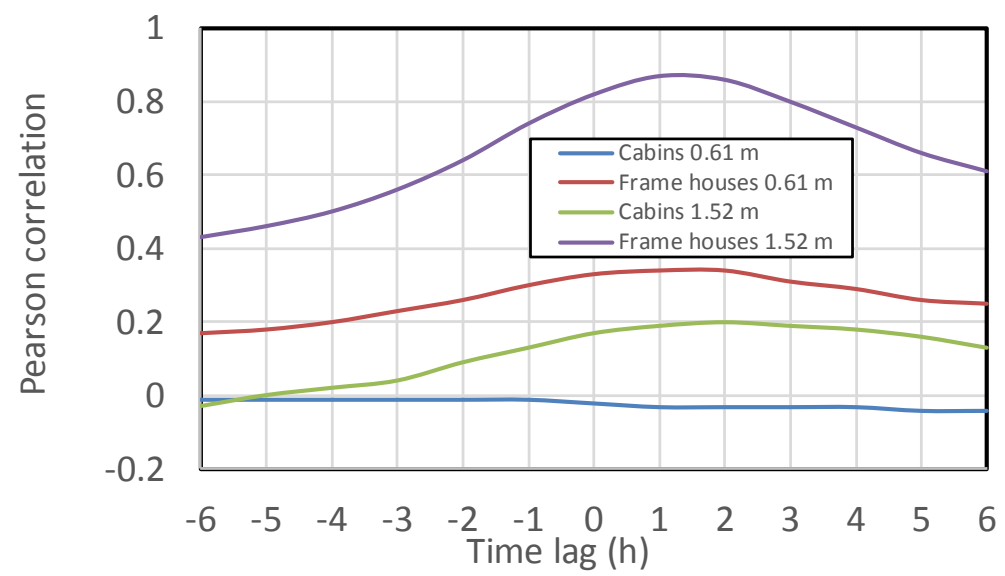

(b)

Figure 7. Correlation between mean (over all sites) indoor and outdoor $\mathrm{PM}_{2.5}$ concentrations at various time lags and heights. 
$33.8 \mu \mathrm{g} \cdot \mathrm{m}^{-3}$ and $137.4 \mu \mathrm{g} \cdot \mathrm{m}^{-3}$ under conditions of no inversions and SBIs, respectively. The mean of the few available data in September during times of SBIs was $76.2 \mu \mathrm{g} \cdot \mathrm{m}^{-3}$, while not enough data existed to calculate a mean for non-inversion conditions.

These findings can be explained as follows. In April and September, heating is still and already again needed. Woodstoves release $\mathrm{PM}_{2.5}$ and its precursor gases during operation. Typically, they are used for heating during the day and are fed once more prior to bedtime. Once all wood is burned, these emissions stop. When indoor temperatures fall below the monitor-set threshold, the furnace turns on. The emissions from diesel heating mostly leave via the chimney. Furthermore, settled particles are not re-suspended when the residents are sleeping. Consequently, $\mathrm{PM}_{2.5}$ concentrations were lower during nighttime than daytime. Since, most inversions occurred at night (cf. Figure 4), indoor concentrations were lower during inversions than no inversion conditions in the heating season (Table 5). People are awake the majority of the time during the day when no surface inversion exists. Consequently, due to their activities $\mathrm{PM}_{2.5}$ concentration levels were highest indoors during this time.

\subsubsection{Relation between Indoor Air Quality and Building Type}

To examine the relation between construction types and building use, we averaged the hourly mean indoor $\mathrm{PM}_{2.5}$ concentrations for each construction type and measurement level. Furthermore, we calculated hourly concentration means for residencies and office building by averaging over all respective sites.

Typically, hourly mean values at $0.61 \mathrm{~m}$ and $1.52 \mathrm{~m}$ heights correlated weakly (27.4\%) and hardly (1.5\%) for frame houses and cabins, respectively (Figure $7(b))$. This means that indoor air quality of frame houses is stronger related to outdoor air quality than indoor air quality of cabins. On average, in frame houses, concentrations were higher at $0.61 \mathrm{~m}$ than $1.52 \mathrm{~m}$, while the opposite was observed in cabins (cf. Figure 6(b), Figure 8). Daily 24-h mean indoor $\mathrm{PM}_{2.5}$ concentrations at both heights for the greater part exceeded the NAAQS frequently (Figure 8).

On average, cabin indoor $\mathrm{PM}_{2.5}$ concentrations at $0.61 \mathrm{~m}$ height were higher during times without inversions than during SBIs (Table 5). The same is true for frame houses in April and September, while the opposite was true from May to August (Table 5).

At $1.52 \mathrm{~m}$ height, means of both cabin and frame house indoor $\mathrm{PM}_{2.5}$ concentrations were higher for times with than without inversions in all months (Table 6). Cabins provided the lowest exposure at both heights (Table 5, Table 6). No data were available at $0.61 \mathrm{~m}$ height for cabins in March and September. Only few $\mathrm{PM}_{2.5}$ data were available at $0.61 \mathrm{~m}$ height for frame houses in March. This means the March values for frame houses are the same as those for residencies, namely $33.8 \mu \mathrm{g} \cdot \mathrm{m}^{-3}$ and $137.4 \mu \mathrm{g} \cdot \mathrm{m}^{-3}$ during times without and with SBI, respectively. The mean indoor $\mathrm{PM}_{2.5}$ concentrations over all September data during inversions were $76.2 \mu \mathrm{g} \cdot \mathrm{m}^{-3}$ at $0.61 \mathrm{~m}$ height. 


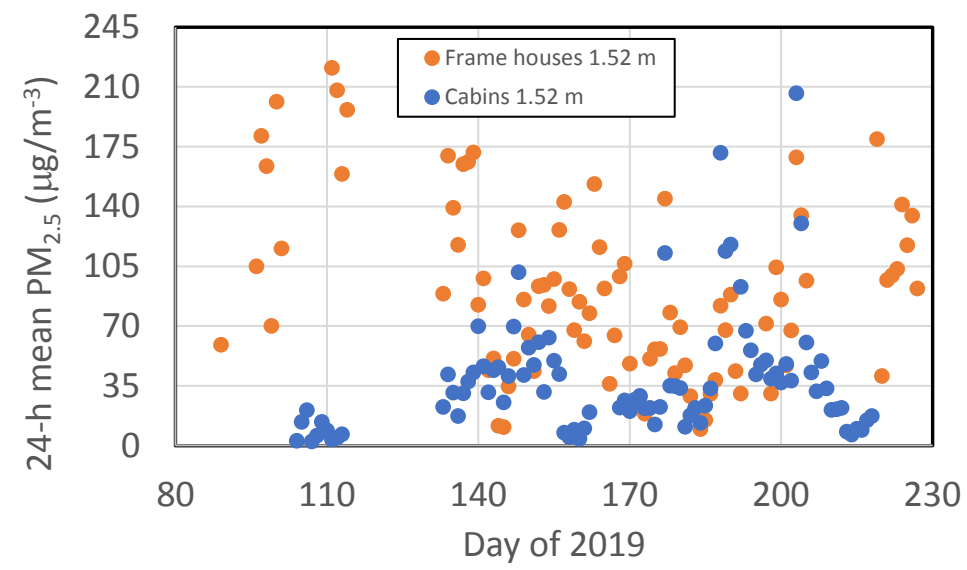

(a)

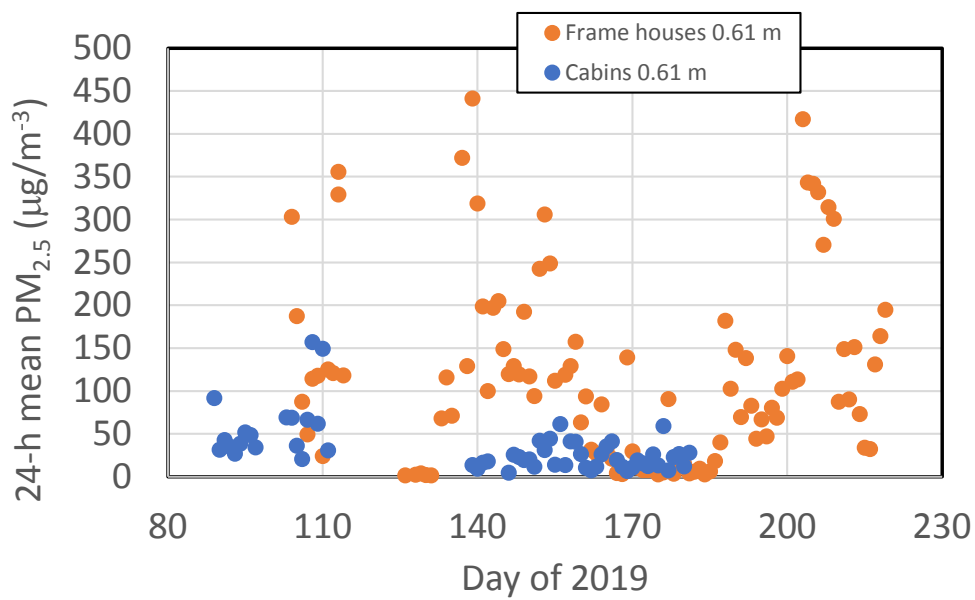

(b)

Figure 8. Temporal evolution of 24-h mean $\mathrm{PM}_{2.5}$ concentrations.

These insights suggest that in frame houses, sleeping on top-bunks seems to be beneficial for health except during wildfires. Also cabins seem to be superior over frame houses in keeping outside $\mathrm{PM}_{2.5}$ concentrations at bay.

Recall no measurements were made at $0.61 \mathrm{~m}$ height in office/commercial buildings because nobody sleeps in them. In April and May, concentrations at $1.52 \mathrm{~m}$ were higher in residences than office/commercial buildings both during times with and without SBI (cf. Table 6). At night, office/commercial buildings are closed meaning that particulate matter settled. Consequently, $1.52 \mathrm{~m}$ concentrations went down as compared to the times without SBI, i.e. during the day. The higher concentrations in residences than office/commercial buildings during times without SBI can be explained by the different kind of indoor activities, emissions sources and emission rates at home and work.

In JJA, monthly mean and 24-h mean $\mathrm{PM}_{2.5}$ concentrations in office/commercial buildings exceeded those in residences (cf. Table 6, Table 7, Figure 8, Figure 9). For both, concentrations were higher during SBI than during times without SBI (Table 6). The reasons for this shift in concentration behavior are as follows. In JJA, residents were involved in activities related to the various harvest seasons 


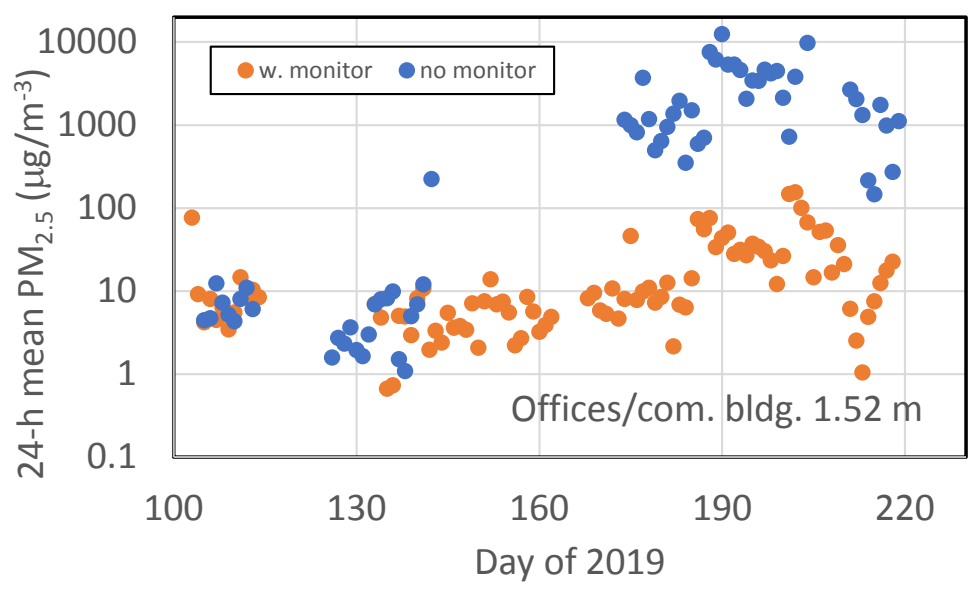

Figure 9. Temporal evolution of 24 h-mean $\mathrm{PM}_{2.5}$ concentrations averaged over all office/commercial buildings with and without temperature monitor.

(e.g. fishing, berry picking, hunting). Hence, they stayed less time inside or even stayed outside of town in seasonal camps. Consequently, resuspension due to inside activities were reduced in residencies as compared to April and May, when residents spent more time inside. Absence also meant less emissions from mosquito pics as compared to offices/commercial buildings.

As aforementioned, in summer, the population quadruples due to tourists and fire fighters stationed at Ft. Yukon. Thus, office and commercial buildings have not only more public traffic in JJA than April and May, but also longer business hours to serve the increased demand. Furthermore, more emissions occur inside due to increased amounts of merchandise, use of equipment and cooling. Mosquito pics serve to hold mosquitoes at bay during the day. The increase in customers also leads to an increase in activities for restocking. During the day, customer traffic led to air exchange between indoor and outdoor air. At night, no such ventilation existed. Thus, the increased indoor emissions accumulated inside. Consequently, inside concentrations during the nighttime SBI exceeded those observed at daytime.

\subsubsection{Impact of Temperature Monitors in Office/Commercial Buildings}

Various studies indicated that in Fairbanks, wood burning is the major cause for exceedances of the outdoor NAAQS (e.g. [27] [28]). Simulations with the Weather Research Forecast model coupled with chemistry packages (WRF-Chem) showed that using both low sulfur fuel and EPA certified wood stoves reduced the concentrations of $\mathrm{PM}_{2.5}$ as compared to the old devices used in Fairbanks [28]. Therefore, we examined the impacts of temperature monitors on indoor air quality of office/commercial buildings. All residences had a monitor and burned both wood and diesel, while office/commercial buildings only burned fuel.

In office/commercial buildings without temperature monitor, monthly and 24-h mean $\mathrm{PM}_{2.5}$ concentrations were up to more than two orders of magnitude higher than in office buildings with monitors during JJA (Table 7, Figure 9). This means that using a temperature monitor could reduce exposure of em- 
ployees, clients and customers in summer. In April, office and commercial buildings without monitor have lower $\mathrm{PM}_{2.5}$ concentrations than those with monitor. This finding can be explained by the monitor and hence furnace reacting to changes in indoor temperature caused by opening and closing of doors during business hours. However, in both cases, $\mathrm{PM}_{2.5}$ concentrations remain in the healthy range.

\section{Conclusions and Recommendations}

The exposure of rural communities in the Yukon Flats to $\mathrm{PM}_{2.5}$, concentrations was assessed by measurements at 20 indoor and four outdoor sites from March 2019 to September 2019 using Ft Yukon as a testbed. In residences, $\mathrm{PM}_{2.5}$ was measured at $0.61 \mathrm{~m}$ and $1.52 \mathrm{~m}$ heights; while in office/commercial buildings, data were taken at $1.52 \mathrm{~m}$. Outdoor observations included meteorological data in addition to $\mathrm{PM}_{2.5}$.

On average, $\mathrm{PM}_{2.5}$ outdoor concentrations were well below $25 \mu \mathrm{g} \cdot \mathrm{m}^{-3}$ and decreased from March to May due to decreasing inversion durations and heating. June outdoor $\mathrm{PM}_{2.5}$ concentrations were below this value except when wildfire smoke was advected. July mean outdoor concentration of $\mathrm{PM}_{2.5}$ was $55.3 \mu \mathrm{g} \cdot \mathrm{m}^{-3}$. When in the downwind of wildfires, outdoor $\mathrm{PM}_{2.5}$ concentrations often exceed the 24-h US NAAQS of $35 \mu \mathrm{g} \cdot \mathrm{m}^{-3}$ and in some hours even reached hazardous conditions.

While indoor air quality was moderate in March, it decreased towards summer to hazardous levels on monthly mean and also exceeded those observed outside for notable amounts of time for all building types. Typically, concentrations were lower in cabins than frame houses. In frame houses, $\mathrm{PM}_{2.5}$ concentrations were higher at $0.61 \mathrm{~m}$ than $1.52 \mathrm{~m}$, while the opposite was true in cabins.

Based on these findings one has to conclude that 1) The new log cabins in Fort Yukon provide better indoor air quality conditions than modern frame homes; 2) Sleeping on bunk beds would be beneficial for health in frame houses; 3) $\mathrm{Yu}$ kon Flats communities are exposed to hazardous indoor $\mathrm{PM}_{2.5}$ concentrations all summer.

On average, there was a one-hour time-lag between changes of indoor and outdoor air quality conditions. Cabins had the lowest correlation between indoor and outdoor $\mathrm{PM}_{2.5}$ concentrations followed by frame houses and office/commercial buildings with the highest correlation. Therefore, one has to conclude that frame homes have a higher ventilation and air exchange than cabins, and that frequent opening and closing of doors during hours of customer traffic increased air exchange. The additional emissions from increased amounts of merchandise and/or increased use of equipment in office/commercial buildings and mosquito pics caused hazardous $\mathrm{PM}_{2.5}$ concentrations at breathing level. Implementation of a temperature monitor could reduce indoor $\mathrm{PM}_{2.5}$ concentrations by about two orders of magnitude. According to a study in Libby, Montana a change-out program for wood and cooking stoves could improve 
indoor air quality by $53 \%$ [29].

\section{Acknowledgements}

We thank the residents, business owners and office manager of Ft. Yukon who volunteered their homes and office/commercial buildings as measurement sites, and the anonymous reviewers for fruitful discussion and comments. The Tribal Resilience Program, NSF SOARS program grant \#1641177 and the Mellow Graduate Student Fellowship as well as the State of Alaska provided financial support for this study.

\section{Conflicts of Interest}

The authors declare no conflicts of interest regarding the publication of this paper.

\section{References}

[1] Hodas, N., Loh, M., Shin, H.-M., Li, D., Bennett, D., Mckone, T.E., Jolliet, O., Weschler, C.J., Jantunen, M., Lioy, P. and Fantke, P. (2016) Indoor Inhalation Intake Fractions of Fine Particulate Matter: Review of Influencing Factors. Indoor Air, 26, 836-856. https://doi.org/10.1111/ina.12268

[2] Berglund, B., Brunekreef, B., Knöppe, H., Lindvall, T., Maroni, M., Mølhave, L. and Skov, P. (1992) Effects of Indoor Air Pollution on Human Health. Indoor Air, 2, 2-25. https://doi.org/10.1111/j.1600-0668.1992.02-21.x

[3] Tham, K.W. (2016) Indoor Air Quality and Its Effects on Humans-A Review of Challenges and Developments in the Last 30 Years. Energy and Buildings, 130, 637-650. https://doi.org/10.1016/j.enbuild.2016.08.071

[4] Kramm, G., Beheng, K.D. and Müller, H. (1992) Modeling of the Vertical Transport of Polydispersed Aerosol Particles in the Atmospheric Surface Layer. In: Schwartz, S. and Slinn, W.G.N., Eds., Precipitation Scavenging and Atmosphere-Surface EXchange, Hemisphere Publishing Corporation, Washington DC, 1125-1141.

[5] Finlayson-Pitts, B.J. and Pitts, J.N.J. (2000) Chemistry of the Upper and Lower Atmosphere. Academic Press, Cambridge.

[6] US Environmental Protection Agency (2011) Exposure Factors Handbook. No. EPA/600/R-09/052F. http://www.epa.gov/ncea/efh

[7] Mölders, N. and Kramm, G. (2014) Lectures in Meteorology. Springer, Heidelberg, 591. https://doi.org/10.1007/978-3-319-02144-7

[8] Chatzidiakou, L., Mumovic, D. and Summerfield, A.J. (2012) What Do We Know about Indoor Air Quality in School Classrooms? A Critical Review of the Literature. Intelligent Buildings International, 4, 228-259. https://doi.org/10.1080/17508975.2012.725530

[9] Challoner, A. and Gill, L. (2014) Indoor/Outdoor Air Pollution Relationships in Ten Commercial Buildings: $\mathrm{PM}_{2.5}$ and $\mathrm{NO}_{2}$. Building and Environment, 80, 159-173. https://doi.org/10.1016/j.buildenv.2014.05.032

[10] Wang, Y., Chen, C., Wang, P., Wan, Y., Chen, Z. and Zhao, L. (2015) Experimental Investigation on Indoor/Outdoor $\mathrm{PM}_{2.5}$ Concentrations of an Office Building Located in Guangzhou. Procedia Engineering, 121, 333-340.

https://doi.org/10.1016/j.proeng.2015.08.1076 
[11] Fleisch, A.F., Rokoff, L.B., Garshick, E., Grady, S.T., Chipman, J.W., Baker, E.R., Koutrakis, P. and Karagas, M.R. (2020) Residential Wood Stove Use and Indoor Exposure to $\mathrm{PM}_{2.5}$ and Its Components in Northern New England. Journal of EXposure Science \& Environmental Epidemiology, 30, 350-361. https://doi.org/10.1038/s41370-019-0151-4

[12] Liu, J.C., Pereira, G., Uhl, S.A., Bravo, M.A. and Bell, M.L. (2015) A Systematic Review of the Physical Health Impacts from Non-Occupational Exposure to Wildfire Smoke. Environmental Research, 136, 120-132. https://doi.org/10.1016/j.envres.2014.10.015

[13] Edwin, S.G. and Mölders, N. (2018) Particulate Matter Exposure of Rural Interior Communities as Observed by the First Tribal Air Quality Network in the Yukon Flat. Journal of Environmental Pollution. https://doi.org/10.4236/jep.2018.913088

[14] Mölders, N., Fochesatto, G.J., Edwin, S.G. and Kramm, G. (2019) Geothermal, Oceanic, Wildfire, Meteorological and Anthropogenic Impacts on $\mathrm{PM}_{2.5}$ Concentrations in the Fairbanks Metropolitan Area. Open Journal of Air Pollution, 8, 50. https://doi.org/10.4236/ojap.2019.82002

[15] Stocks, B.J., Fosberg, M.A., Lynham, T.J., Mearns, L., Wotton, B.M., Yang, Q., Jin, J.Z., Lawrence, K., Hartley, G.R., Mason, J.A. and Mckenney, D.W. (1998) Climate Change and Forest Fire Potential in Russian and Canadian Boreal Forests. Climatic Change, 38, 1-13. https://doi.org/10.1023/A:1005306001055

[16] EPA $(2015,2011)$ National Ambient Air Quality Standards (NAAQS). https://doi.org/10.1289/isee.2015.2015-622

[17] World Health Organization (WHO) (2017) Air Quality Guidelines.

[18] Kim, J., Waliser, D.E., Mattmann, C.A., Mearns, L.O., Goodale, C.E., Hart, A.F., Crichton, D.J., Mcginnis, S., Lee, H., Loikith, P.C. and Boustani, M. (2013) Evaluation of the Surface Climatology over the Conterminous United States in the North American Regional Climate Change Assessment Program Hindcast Experiment Using a Regional Climate Model Evaluation System. Journal of Climate, 26, 5698-5715. https://doi.org/10.1175/JCLI-D-12-00452.1

[19] EPA (2007) Guidance on the Use of Models and Other Analyses for Demonstrating Attainment of Air Quality Goals for Ozone, $\mathrm{PM}_{2.5}$, and Regional Haze. EPA-454/B-07-002, 262.

[20] Edwin, S. and Mölders, N. (2020) Mesoscale Impacts on Cold Season $\mathrm{PM}_{2.5}$ in the Yukon Flats. Journal of Environmental Protection, 11, 215-240. https://doi.org/10.4236/jep.2020.113013

[21] Weilenmann, M., Favez, J.-Y. and Alvarez, R. (2009) Cold-Start Emissions of Modern Passenger Cars at Different Low Ambient Temperatures and Their Evolution over Vehicle Legislation Categories. Atmospheric Environment, 43, 2419-2429. https://doi.org/10.1016/j.atmosenv.2009.02.005

[22] Mölders, N. and Kramm, G. (2018) Climatology of Air Quality in Arctic Cities-Inventory and Assessment. Open Journal of Air Pollution, 7, 48-93. https://doi.org/10.4236/ojap.2018.71004

[23] Tran, T.D., Nguyen, P.M., Nghiem, D.T., Le, T.H., Tu, M.B., Alleman, L.Y., Nguyen, V.M., Pham, D.T., Ha, N.M., Dang, M.N., Le, C.V. and Nguyen, N.V. (2020) Assessment of Air Quality in School Environments in Hanoi, Vietnam: A Focus on Mass-Size Distribution and Elemental Composition of Indoor-Outdoor Ultrafine/Fine/Coarse Particles. Atmosphere, 11, 519. https://doi.org/10.3390/atmos11050519

[24] Zhou, Z., Liu, Y., Yuan, J., Zuo, J., Chen, G., Xu, L. and Rameezdeen, R. (2016) In- 
door $\mathrm{PM}_{2.5}$ Concentrations in Residential Buildings During a Severely Polluted Winter: A Case Study in Tianjin, China. Renewable and Sustainable Energy Reviews, 64, 372-381. https://doi.org/10.1016/j.rser.2016.06.018

[25] Song, P., Wang, L., Hui, Y. and Li, R. (2015) $\mathrm{PM}_{2.5}$ Concentrations Indoors and Outdoors in Heavy Air Pollution Days in Winter. Procedia Engineering, 121, 1902-1906. https://doi.org/10.1016/j.proeng.2015.09.173

[26] von Storch, H. and Zwiers, F.W. (1999) Statistical Analysis in Climate Research. 484. https://doi.org/10.1007/978-3-662-03744-7_2

[27] Tran, H.N.Q. and Mölders, N. (2012) Wood-Burning Device Changeout: Modeling the Impact on $\mathrm{PM}_{2.5}$ Concentrations in a Remote Subarctic Urban Nonattainment Area. Advances in Meteorology, 2012, Article ID: 853405.

https://doi.org/10.1155/2012/853405

[28] Mölders, N. (2013) Investigations on the Impact of Single Direct and Indirect, and Multiple Emission-Control Measures on Cold-Season Near-Surface $\mathrm{PM}_{2.5}$ Concentrations in Fairbanks, Alaska. Atmospheric Pollution Research, 4, 87-100. https://doi.org/10.5094/APR.2013.009

[29] Noonan, C.W., Navidi, W., Sheppard, L., Palmer, C.P., Bergauff, M., Hooper, K. and Ward, T.J. (2012) Residential Indoor $\mathrm{PM}_{2.5}$ in Wood Stove Homes: Follow-Up of the Libby Changeout Program. Indoor Air, 22, 492-500.

https://doi.org/10.1111/j.1600-0668.2012.00789.x 